\title{
Attitudes, Perceptions and Motivations of Libyan Retail Consumers toward Islamic Methods of Finance ${ }^{\dagger}$
}

\author{
Alsadek H. Gait and Andrew C. Worthington ${ }^{\ddagger}$ \\ Griffith Business School, Griffith University
}

\begin{abstract}
This paper reports the results of a survey of 385 Libyan retail consumers in December 2007February 2008 used to gather attitudes, perceptions and motivations towards Islamic methods of finance. The results indicate that while most respondents have at least some knowledge about some aspects of Islamic finance, specifically Musharakah (full-equity business partnerships) and Quard Hassan (interest-free benevolent loans), they are generally unaware of many other related products. Nonetheless, most respondents (85.9\%) are potential users of Islamic methods of finance at the retail level, though potential use varying markedly according to age, level of education, employment, income and nationality. Factor analysis reduces the large number of variables that determine retail consumers' attitudes, perceptions and motivations towards Islamic methods of finance to just four determinants: namely, community service, profitability, religion and unique services. Discriminant analysis shows that religion and community service are the most important factors determining the potential use of Islamic methods of finance by retail consumers in Libya.
\end{abstract}

JEL classification: D14; G20; O16

Keywords: Islamic methods of finance; Islamic banking; consumer attitudes and perceptions.

\section{Introduction}

Islamic finance-financial institutions, products, and services designed to comply with the central tenets of Sharia (Islamic law) — is one of the most rapidly growing segments of the global finance industry. Starting with the Dubai Islamic Bank in 1975 (and operations in the United Arab Emirates, Egypt, the Cayman Islands, Sudan, Lebanon, the Bahamas, Bosnia, Bahrain and Pakistan), the number of Islamic financial institutions worldwide now exceeds over 300, with operations in 75 countries and assets in excess of US\$400 billion (El-Qorchi, 2005).

Though initially concentrated in the Middle East (especially Bahrain) and South East Asia (particularly Malaysia), Islamic finance principles are now increasingly found elsewhere. This includes developing economies where the financial sector is almost entirely Islamic (Iran and Sudan) or where Islamic and 'conventional' financial systems coexist (Indonesia, Malaysia, Pakistan and the United Arab Emirates) (El-Qorchi, 2005). It also includes developed

\footnotetext{
${ }^{\dagger}$ Paper presented to the Asian Finance Association 2009 International Conference, Brisbane, 30 June-3 July, 2009.

₹ Presenting author: Department of Accounting, Finance and Economics, Griffith University, Nathan QLD 4111, Australia. Tel. +61 (0)7 3735 4273; Fax. +61 (0)7 3735 3719; Email. a.worthington@griffith.edu.au.
} 
economies where a small number of Islamic financial institutions have been established and where large conventional banks have opened Islamic financing windows (as in Europe and the United States).

However, while Islamic finance has been practiced for many centuries, it is important to recall that only in the last thirty years have Islamic financial institutions offering Sharia-compliant products and services become more widespread and important. Indeed, even in Muslim countries it is only very recently that analogous Islamic finance products and services have been offered in direct competition to the financial products and services offered by conventional banks. Clearly, as Islamic products and services enter these markets, an important consideration is the attitudes, perceptions and knowledge of market participants towards these new methods of finance (Gait and Worthington 2008). For individual consumers and business firms, these factors determine the extent to which they choose to patronize these alternative products and services. Key concerns include the influence of religious persuasion and the relative pricing, costs and benefits, convenience and access of Islamic products and services vis-à-vis conventional bank products and services. For conventional financial institutions, the presence of financial institutions offering Islamic financial products and services may affect their competitive position and how they construct new marketing strategies. It may also influence to their decision to introduce Shariacompliant products and services themselves.

Libya provides an interesting context to examine these issues. First, while the majority of the population are Muslims, there are presently no Islamic financial institutions operating in Libya. Second, the Libyan government is increasingly moving towards the liberalisation and reform of the country's financial system and part of this process foresees the contribution of Islamic financial institutions, products and services. Finally, there is no published work on Libyan retail consumers and limited international study of attitudes towards Islamic methods of finance more generally. This purpose of this paper is then to provide the results of a survey of Libyan retail consumers on their attitudes, perceptions and motivations towards Islamic methods of finance. The paper is structured as follows. Section 2 provides a brief review of Islamic finance, including its sources, principles and most-common products and services. Section 3 discusses the literature on individual consumers' attitudes towards Islamic finance and Section 4 presents the sample methodology. Section 5 provides some descriptive statistics and Section 6 the main empirical results. The final section concludes the paper. 


\section{Islamic finance}

Islamic finance is defined as a financial service or product principally implemented to comply with the main tenets of Sharia (or Islamic law). In turn, the main sources of Sharia are the Holy Quran, Hadith, Sunna, Ijma, Qiyas and Ijtihad. The Holy Quran is the book of revelation given to the Prophet Muhammad; Hadith is the narrative relating the deeds and utterances of Muhammad; Sunna refers to the habitual practice and behaviour of Muhammad during his lifetime; Ijma is the consensus among religion scholars about specific issues not envisaged in either the Holy Quran or the Sunna; Qiyas is the use of deduction by analogy to provide an opinion on a case not referred to in the Quran or the Sunna in comparison with another case referred to in the Quran and the Sunna; and Ijtihad represents a jurists' independent reasoning relating to the applicability of certain Sharia rules on cases not included in either the Quran or the Sunna.

In brief, the principles of Islamic finance are as follows: (i) the prohibition of Riba (usually interpreted as usury or interest) and the removal of debt-based financing; (ii) the prohibition of Gharar, encompassing the full disclosure of information, removal of asymmetric information in contracts and the avoidance of risk-taking; (iii) the exclusion of financing and dealing in activities and commodities regarded as sinful or socially irresponsible (such as gambling, alcohol and pork); (iv) an emphasis on risk-sharing, the provider of financial funds and the entrepreneur share business risk in return for a pre-determined share of profits and losses; (v) the desirability of materiality, a financial transaction needs to have 'material finality', that is a direct or indirect link to a real economic transaction; and (vi) consideration of justice, a financial transaction should not lead to the exploitation of any party to the transaction [see El-Gamal (2000), Warde (2000), Lewis and Algaoud (2001), Iqbal and Llewellyn (2002), Abdul-Gafoor (2003), Obaidullah (2005), Iqbal and Molyneux (2005) and Gait and Worthington (2009) for suitable introductions to Islamic finance]

In practical terms, these prohibitions and recommendations manifest themselves as the following commercial products and services offered by Islamic financial institutions: (i) Mudarabah, the provision of capital to a partial-equity partnership in return for a share of profits, but where the losses on funds lent are borne by the lender; (ii) Musharakah, fullequity partnerships where the provider of funds and the entrepreneur directly and wholly share in the business, (iii) Murabaha, an instrument used for financing the purchase of goods and services where the financial institution purchases these on behalf of the customer; (iv) Bai muajjall, deferred payments on products encompassed under Murabaha; (v) Bai Salam, 
advance or pre-paid sale contracts of goods and services; (vi) Istisna, or manufacturing contracts to cover work in progress and paid by the financial institution on behalf of the customer; (vii) Ijarah, lease financing in the form of operating leases only; (viii) Takaful or Islamic insurance in the form of cooperative self-help schemes, and (ix) Quard Hassan, benevolent loans offered interest free.

In turn, these commercial products and services underlie the various depositor and investor accounts offered to retail customers. In terms of Islamic banks, these are again very similar to the products and services offered by conventional banks with the exception that Islamic financing principles apply to the underlying bank assets and liabilities. For example, unlike a conventional savings account, interest is forbidden on balances in Islamic accounts. Depositors can, however, obtain benefits in the form of 'voluntary prizes', whose value depends, in part, on the deposit's balance and the bank's profitability. These services are often offered fee-free to depositors.

Islamic products and services also increasingly manifest themselves as mutual funds underpinned by investments in Sharia-compliant equity or property, Sukuk (Islamic bonds), Takaful (Islamic insurance) or Ijarah (Islamic leasing) constructed with Islamic principles in mind. For example, a Sharia-compliant equity mutual fund would, through a process of sector screening and dividend 'purification', normally exclude: banking, insurance or any other interest-related activity; alcohol, tobacco, gambling, armaments; any activity related to pork; other activities deemed offensive to Islam; and any sectors or companies significantly affected by any of the above.

\section{Literature review}

Erol and El-Bdour (1989) and Erol, Kaynak, and El-Bdour (1990) are considered the first studies of consumer attitudes towards Islamic banking. In general, there is much agreement between these two studies on the high level of awareness of Islamic banking in Jordan and that a fast and efficient service and the bank's reputation were significant factors for the choice of a bank. However, religious motivation had no significant effect on the use of Islamic banking services. Omer (1992) surveyed 300 Muslims in the UK on their patronage and awareness of Islamic financing methods. The main finding was that a high level of ignorance prevailed among UK Muslims concerning the principles of Islamic finance. However, while largely ill informed, religious motivation still comprised the most significant factor in their strong preference for Islamic banking services. 
Metwally (1996) also used factor analysis to study the attitudes of Muslims in three Arabic dual-banking systems (Kuwait, Saudi Arabia and Egypt) towards Islamic banking. On this basis, and similarly to Omer (1992), it was concluded that religion was the primary factor in the choice of an Islamic banking institution. Regardless, and similarly to Erol and El-Bdour (1989), Erol, Kaynak, and El-Bdour (1990) and Haron, Ahmad and Planisek (1994) observed that Islamic bank consumers still rated the speed and efficiency of banking services near the top of their bank selection criteria. Haron, Ahmad and Planisek (1994) likewise highlighted the differences in the patronage of Islamic and conventional banks in their study of Muslims and non-Muslims in Malaysia. As in Erol and El-Bdour (1989) and Erol, Kaynak, and ElBdour (1990), factor analysis showed that religious motivation was not the primary reason for Muslims dealing with Islamic banks. The findings also suggested that while Malaysian Muslims and non-Muslims were aware of the existence of Islamic banks, they were usually uninformed of specific Islamic financing methods.

In Bahrain, Metawa and Almossawi (1998) concluded that the most important factors in determining the attitudes of Islamic bank consumers were religion followed by profitability. In Jordan, Naser Naser, Jamal and Al-Khatib (1999) extended the early work by Erol and ElBdour (1989) and Erol, Kaynak, and El-Bdour (1990), but concluded that bank reputation and religious beliefs were the two most important factors motivating the use of Islamic banks services. And in Kuwait, Al-Sultan (1999) considered the attitudes of consumers towards the products and services offered by the interest-free Kuwait Finance House. In the same way as Metwally (1996), Al-Sultan (1999) confirmed that adherence to Islam was the primary motivating factor for Kuwaitis dealing with an Islamic bank. In Singapore, Gerrard and Cunningham (1997) also considered attitudes towards Islamic banking, though in the context of a banking system where no Islamic banks were yet present. While the results showed, not entirely expectedly, that non-Muslims were completely unaware of Islamic methods of finance, Muslims often fared little better. Once again, fast and efficient service and confidentiality were the primary motivations for bank selection.

Later, Hamid and Nordin (2001) focused on the awareness of Malaysian consumers towards Islamic banking within the context of the wider promotion of Islamic education. They found that most Malaysians did not differentiate between Islamic and conventional bank products and services, though the majority had sufficient knowledge of the existence and services offered by Malaysian Islamic banks. Moreover, even though half of the respondents currently dealt with Islamic banks, they were still in need of additional understanding of Islamic bank 
products. Bley and Kuehn (2004) surveyed business students in the United Arab Emirates (Sharjah) on their knowledge of financial aspects of Islamic and conventional banks. The major finding was that Muslim students preferred Islamic banking services because of religious motivations. A secondary finding was that while Arabic Muslims displayed a high level of knowledge of Islamic financial terms and concepts, non-Arabic Muslims students had a higher level of knowledge of conventional banking. In Turkey, customer satisfaction with interest-free banking and bank selection criteria has been considered by Okumkus (2005). The most important finding was that the majority of Islamic bank consumers responded that religion was the primary motivation in their use of Islamic products and services. A second motivation was that the Islamic financial institutions in question also offered conventional bank products and services.

Dusuki and Abdullah (2007) focused on the customers of two Islamic banks in Malaysia: the Bank Islamic Malaysia Berhad and Bank Muamalat Malaysia Berhad. Their findings are consistent with many earlier Islamic banking patronage studies where the quality of service delivery, including staff friendliness and competency and an efficient and speedy service were important factors in influencing bank selection. In addition, they also found that older, relatively well-educated, low and middle-income customers prefer Islamic banks.

Finally, in Adelaide Rammal and Zurbruegg (2007) surveyed 300 Muslims regarding their awareness of Islamic banking products. Their results indicated that the majority of respondents are interested in and prepared to use Islamic methods of finance, but do not know how they function. In other words, even though most respondents have knowledge about the availability of Islamic financial products, they are still unaware of basic Islamic banking principals and methods. This finding is supported by much of the extant literature, including Okumus (2005), Bley and Kuehn (2004), Hamid and Nordin (2001), Naser, Jamal and AlKhatib (1999), and Haron, Ahmad and Planisek (1994). However, Rammal and Zurbruegg (2007) countered that a lack of awareness and experience with halal (food seen as permissible according to Islamic law) does not appear detrimental to consumer willingness to use these products. Somewhat more prosaically, the respondents also indicated the potential use of Islamic financial products as long as the bank made ATM and phone banking available.

\section{Sample methodology}

We designed a questionnaire to collect data from Libyan consumers. To ensure the speed of data collection, control of the sample, good flexibility, and reasonable cost, we collected the 
data through telephone interviews. The main advantages of this method of collection are it allows the opportunity to reduce any potential confusion by the respondent on the questions asked and obtains a relatively high response rate. The sample for Libyan consumers is selected randomly in accordance with a 95 per cent confidence level. The sample size of 385 was determined using a proportion $(\pi)$ of .05 (the safest possible assumption), a confidence level of $95 \%$ corresponding to a Z-value of 1.96 , and an error $(E)$ of 0.05 . The optimal sample size $N$ is then:

$$
N=\pi(1-\pi) Z^{2} / E^{2} \quad \mathrm{~N}=(0.5)(0.5)(1.96)^{2} /(0.05)^{2} \quad N=384.16
$$

Before undertaking the data collection, we interviewed a focus group, also through telephone interviews. This group comprised 20 (pre-screened) respondents representing about $5 \%$ of the sample. We used these interviews to ensure the effectiveness and timeliness of the questionnaire for data collection.

Following the focus group interviews, we conducted the survey from December 2007 to February 2008. We randomly selected respondents using systematic sampling. First, the population size is the telephone directory for Libya's four largest cities: Tripoli, Benghazi, Misratah and Al Murgub. The directory included 79,056 private phone numbers (i.e. $N=$ $79,056)$ in these cities. Second, dividing $N$ by the sample size $n=385$, gives a sample interval of 205. Third, we selected a random number between 1 and 205 using a table of random numbers. As this number was 48, the sample consisted of elements 48, 253 (i.e. $28+205$ ), 458 (i.e. $253+205$ ), 663 (i.e. $458+205$ ) and so on. Finally, using the telephone directory as a sampling frame, we ordered the elements alphabetically. When the number dialled was not successful, we used the next number on the same page.

In the first part of the questionnaire (available from the authors upon request in Arabic and English), the respondents were requested to indicate their knowledge about Islamic banks and their methods of finance. We used the second part of the questionnaire to gather the respondents' attitudes towards Islamic methods of finance. This study uses a seven-point scale from 1 to 7 where 1 is not important at all and 7 is very important for 16 statements that represent reasons for the use of Islamic methods of finance. The questionnaire collected information on the socioeconomic characteristics of the respondents in the final part of the questionnaire.

The methodology used to analyse the survey responses is as follows. First, we use descriptive analysis to examine the degree of awareness of Libyan consumers about Islamic methods of 
finance. Second, we then use factor analysis to identify the main factors that motivate Libyan consumers to apply Islamic methods of finance. Finally, we use discriminant analysis to determine which factors account for the most impact on consumer motivations towards using Islamic methods of finance.

\section{Descriptive statistics}

Table 1 provides several descriptive statistics. Of the 385 respondents, 331 (85.9\%) are potential users of Islamic methods of finance. The respondents (household heads) are also overwhelmingly male: $92.9 \%$ of respondents are male and only $7.1 \%$ are female. According to Al-Nouri (1995, p. 331), Libyan boys are repeatedly reminded of the responsibilities awaiting them upon reaching adulthood, particularly their role as breadwinner, husband and father. However, girls are simply prepared for marriage, motherhood, and housekeeping. Accordingly, women in Libya (and many other Arabic countries) are still not readily welcomed into many aspects of economic life. This socio-cultural stance may account in part for the financial dependency of women in many Islamic countries (Al-Nouri 1993), as evidenced here.

\section{$<$ TABLE 1 HERE $>$}

Over two-thirds (71.6\%) of the respondents are aged from 36 to 55 years and some $45.9 \%$ have attained an education level at the intermediate or secondary level, with about a quarter of respondents completing a university degree. Most of the interviewees (75.8\%) are public servants (i.e. work in the government sector) and only 10.6\% are self-employed. About 54.6\% of respondents have an average monthly income of Libyan Dinar (LYD) 200-300 and approximately 35.8\% have incomes of LYD301-400 (LYD/AUD1.1812). The majority of respondents (97.6\%) are Libyan nationals.

Table 1 also includes statistical tests of the equality of variances and means for the proportion of potential users and nonusers of Islamic finance for each socioeconomic characteristic. As shown, potential users of Islamic finance are more likely to be aged 46 to 55 years, with a high school, diploma or university education, work in the public sector, earn between LYD301-400 per month and are Libyan nationals. Potential non-users of Islamic finance are more likely to be less than 25 years of age, have a primary school education only, be selfemployed, and earn less than LYD200 per month or more than 301LYD per month.

\section{Empirical results}


Table 2 summarises Libyan retail consumers' awareness of Islamic methods of finance. First, approximately $91.1 \%$ of all respondents have knowledge about the existence of Islamic banks. Second Musharakah and Quard Hassan are known by 67.8\% of respondents. Third, Quard Hassan has been practiced by $21 \%$ of respondents in direct informal financing. However, most respondents are uninformed regarding other Islamic financing methods such as Mudarabah, Morabahah, Bai muajjall, Istisna.

\section{$<$ TABLE 2 HERE $>$}

The results in Table 2 suggest that most of the respondents who are aware of Islamic methods of finance are also potential users. More particularly, 92.8\% of 347 consumers are knowledgeable about the existence of Islamic banks, 93.8\% of 261 knowledgeable consumers in Musharakah and Quard Hassan only and 93.9\% of 82 consumers who practiced Quard Hassan only are potential users. In other words, most of the consumers who are generally unaware of Islamic finance (90.3\%) are not potential users. Therefore, and not altogether unexpectedly, awareness of Islamic methods of finance has a positive effect on potential use of Islamic methods of finance.

The respondents indicate their ranking of importance for 16 statements that represent beliefs and evaluated outcomes for the potential use of Islamic methods of finance on a seven-point scale. Table 3 details the means and standard deviations of the variable scores. The data in column 2 suggests that the primary motivations towards Islamic methods of finance are its interest-free nature and religious principles. In contrast, that Islamic banks provide industrial financing (Istisna) and deposits with Islamic bank realising a higher variable rate of return lie at the end of the list of motivations.

\section{$<$ TABLE 3 HERE $>$}

Factor analysis is performed on the explanatory variables with the goal of data reduction. The data in the correlation matrix (not shown) indicates high correlations among the explanatory variables significant at the 0.01 level. This justifies the appropriateness of factor analysis to reduce these highly correlated variables to a smaller more manageable number of factors. However, investigation indicates that the coefficients on the diagonals of the anti-image correlation matrix are greater than 0.5 for each variable. Therefore, there is no need to eliminate any of the variables. Bartlett's test of sphericity is used to test the null hypothesis that the explanatory variables are uncorrelated in the population. The test statistic (7750.584) and p-value $(<0.01)$ reject the null. The Kaiser-Meyer-Olkin measure of sampling adequacy is 
also calculated. A value of 0.803 is obtained, meaning that all of the partial correlation coefficients are small compared to the ordinary correlation coefficients. This also indicates that it is reasonable to proceed with factor analysis. We find that the 16 explanatory variables can be reduced to just four with eigenvalues greater than one. These factors account for about $83.7 \%$ of the total variance.

Table 3 also includes the rotated factor matrix obtained by the varimax procedure. Factor 1 has large coefficients $(>0.5)$ on five variables in bold in column 2. These are: (i) profit/loss sharing method allows you to invest or borrow on a fair basis, (ii) Islamic bank may help in collecting and distribution of Zakah, (iii) Islamic bank aims to serve Muslim communities, (iv) Islamic bank may contribute to the society‘s development, and (v) Islamic bank may help poor people with benevolent loans (Quard Hassan). We refer to this factor as "Community Service” as these perceptions most closely link financial services and the Islamic community. Factor 2 has large coefficients on four variables in bold in column 3. These are (i) deposits with Islamic banks would realise a higher variable rate of return, (ii) Islamic bank's cost of borrowing depends on the outcome of the business, (iii) Islamic bank may invest according to profit sharing method only (Mudarabah), and (iv) Islamic bank lends money according to profit/loss sharing method (Musharakah). As these motivations generally suggest the intention of firms to increase profits and reduce losses we refer to this factor as "Profitability".

Factor 3 has high coefficients on four variables in bold in column 4. These are; (i) Islamic bank methods of finance are interest-free, (ii) Islamic bank provides Islamic methods of finance in accordance with Sharia, (iii) religious motivation for depositing with Islamic bank, and (iv) religious motivation for borrowing from Islamic bank. As these motivations indicate the consumer's willingness to comply with religious principles, we refer to this factor as "Religion". Finally, factor 4 has high coefficients on four variables in bold in column 5 . These are: (i) Islamic bank provides lease financing (Ijarah), (ii) Islamic bank provides trade financing methods such as Morabahah and (iii) Islamic bank provides industrial financing (Istisna). As these variables indicate new methods of finance not offered by the conventional banking system they are referred to as "Unique services”.

These factor scores (Community Service, Profitability, Religion, and Unique Services) are now suitable for use in multivariate analysis. We divide the respondents into two groups: namely, those that are potential users of Islamic methods of finance and those that are not. 
The mean and standard deviation of the factor scores for these groups and all respondents (not shown) suggest that the two groups are most widely separated in terms of the value of factor score 1 (Religion) and 2 (Profitability) while the differences are smallest for factor scores 3 (Community Service) and 4 (Unique Services).

Wilks' Lambda (p-value in brackets) is the proportion of variance not explained by differences between the groups: Community Service $0.740(<0.01)$, Profitability 0.0900 $(<0.01)$, Religion $0.599(<0.01)$, and Unique Services $0.985(<0.01)$. Because all of these values are less than 1 , most of the observed variability in the factor scores can be attributed to the differences between the groups. The polled within-group correlation matrix also indicates relatively low (negative) correlations between the factor scores (Community Service and Profitability, -0.197; Community Service and Religion, -0.484; Community Service and Unique Services, -0.072; Profitability and Religion, -0.272; Profitability and Unique Services, -0.041; and Religion and Unique Services, -0.100).

Box's $M$ (F-statistic $=25.589$, p-value $=<0.01)$ rejects the null hypothesis that the covariance matrices are equal. The eigenvalue (3.443) is quite large and accounts for $100 \%$ of the explained variance. The canonical correlation is another measure of the degree of association between the discriminant scores and the groups. The canonical correlation of the discriminant function is about 0.88 . The square of this coefficient shows that $77.4 \%$ of the variance of the dependent variable (potential use of Islamic methods of finance) is explained or accounted for by this model. Wilks' lambda associated with the discriminant function is 0.225 . This is the ratio of the within-groups sum of squares to the total sum of squares. This can be transformed to a chi-square value of 568.202, which is statistically significant at the 0.01 level with degrees of freedom equal to the number of factor scores. Therefore, it is acceptable to reject the null hypothesis that respondents who are potential users have the same average discriminant function score in the population.

\section{$<$ TABLE 4 HERE $>$}

The absolute magnitude of the standardized canonical discriminant function coefficients suggests that Religion (1.173), Community Service (1.050) and Profitability (0.717) are the most important factors discriminating between potential users and non-users of Islamic methods of finance. Clearly, religion is the primary motivation for the potential use of Islamic methods of finance among retail consumers in Libya, closely followed by Community Service. Another way to assess the relative importance of the predictors can be obtained by 
examining the structure correlations between the values of the function and the values of the variables (not shown). This again indicates that Religion (0.441) is the most important factor for the potential use of Islamic methods of finance by Libyan retail consumers while Profitability (0.179) and Unique Services (0.066) are less important. The classification results in Table 4 show that perceptions held by retail consumers toward Islamic methods of finance are crucial in determining potential usage, with $99.7 \%$ of potential users and $96.3 \%$ of potential non-users correctly classified.

\section{Concluding remarks}

This study establishes that while Islamic finance is not yet formally practiced in Libya, most retail consumers have knowledge about the existence of Islamic banks that apply Islamic methods of finance. Interestingly, they are highly aware of Musharakah (full partnership) and Quard Hassan (interest-free loans). In addition, Quard Hassan is practiced individually by about one-fifth of respondents who have lent one another interest-free loans. In contrast, other Islamic financing methods, such as Mudarabah, Morabahah, Bai muajjall and Istisna, are relatively unknown. The study also suggests that most respondents are potential users of Islamic methods of finance. Factor analysis, using principal components and varimax rotation, reduced the 16 explanatory variables selected to find out Libyan consumers' attitudes towards Islamic methods of finance to just four factors. These are community service, profitability, religion and unique services. Discriminant analysis indicates that the respondents rank religious motivation top of their reasons for the use of Islamic methods of finance, followed by community service and profitability.

A number of directions for further research are indicated. First, little is still known on how Muslims and non-Muslims are affected by religious convictions in their financial decisionmaking. Despite the evolving literature on Islamic finance, much work remains to be done on consumer behaviour using more sophisticated choice modelling techniques and more extensive samples. Second, this work on attitudes, perceptions and knowledge of Islamic finance has been undertaken in a particular national context. It would then be interesting to compare feedback from a survey administered in, say, a country with a predominately Islamic finance system, to a country with a dual-finance system, and another at an early stage of the introduction of Islamic finance. Finally, one reason for the growth of Islamic finance worldwide has been the willingness of national governments with a sectarian-orientation to support its establishment. It is not known what particular role these governments have played 
in attempting to modify the perceptions, attitudes and knowledge of Islamic banking alongside any direct or indirect support or encouragement to the institutions themselves.

\section{References}

Abdul-Gafoor, A. (2003), Islamic Banking. A.S. Noor Deen, Kuala Lumpur.

Al-Nouri, Q (1993). Iraqi Rural Women's Participation in Domestic Decision-making. Journal of Comparative Family Studies. 24(1).

Al-Nouri, Q (1995). University modernizing effects on Libyan Family and culture. Journal of Comparative Family Studies. 26(3): 329-347.

Al-Sultan, W (1999). Financial characteristics of interest-free banks and conventional banks. Ph.D. Dissertation, The University of Wollongong.

Basilevsky, A (1994). Statistical Factor Analysis and Related Methods: Theory and Applications. Wiley. New York.

Bley, J and Kuehn K (2004). Conventional versus Islamic finance: student knowledge and perception in the United Arab Emirates. International Journal of Islamic Financial Services 5(4).

Dusuki, A and Abdullah N (2007). Why do Malaysian customers patronise Islamic banks? International Journal of Bank Marketing. 25(3): 142-160.

El-Gamal, M. (2000), A Basic Guide to Contemporary Islamic Banking and Finance, Available at http://www.witness-pioneer.org/.

El-Qorchi, M (2005). Islamic Finance Gears Up. Finance and Development 42(4): 46-50.

Erol, C and El-Bdour R (1989). Attitudes, behaviour and patronage factors of bank customers towards Islamic banks. International Journal of Bank Marketing 7(6): 31-37.

Erol, C, Kaynak E and El-Bdour R (1990). Conventional and Islamic banks: patronage behaviour of Jordanian customers. International Journal of Bank Marketing 8(4): 25-35.

Gait, A. and Worthington, A.C. (2008) An Empirical Survey of Individual Consumer, Business Firm and Financial Institution Attitudes towards Islamic Methods of Finance, International Journal of Social Economics, 35(11): 783-808.

Gait, A. and Worthington, A.C. (2009) A primer on Islamic finance: Definitions, sources, principles and methods, in Islamic Finance, ICFAI Press, Hyderabad (forthcoming).

Gerrard, P and Cunningham J (1997). Islamic banking: a study in Singapore. International Journal of Bank Marketing 15(6): 204-216.

Hair, F, Anderson R, Tatham R and Black W (1995). Multivariate data analysis with readings. Prentice Hall. New Jersey.

Hamid, A and Nordin N (2001). A study on Islamic banking education and strategy for the new millenniumMalaysian experience. International Journal of Islamic Financial Services 2(4).

Haron, S, Ahmad N and Planisek S (1994). Bank patronage factors of Muslim and non-Muslim customers. International Journal of Bank Marketing 12(1): 32-40.

Hawes, J, Rao C and Baker T (1993). Retail Salesperson Attributes and the Role of Dependability in selection of Durable Goods. Journal of Personal Selling \& Sales Management 13(4): 61-71.

Iqbal, M. and Llewellyn, D. (eds.) (2002), Islamic Banking and Finance: New Perspectives on Profit-Sharing and Risk, Edward Elgar: Cheltenham, UK.

Iqbal, M. and Molyneux, P. (2005), Thirty Years of Islamic Banking: History, Performance, and Prospects, Palgrave Macmillan: New York.

Lewis, M. and Algaoud, L. (2001), Islamic Banking, Edward Elgar, Cheltenham UK.

Malhotra, N (2006). Marketing research: an applied orientation. Pearson Education Australia. Frenchs Forest.

Malhotra, N and Birks D (2003). Marketing research: an applied approach. FT Prentice Hall. Harlow. 
Metawa, S and Almossawi M (1998). Banking behaviour of Islamic bank customers: perspectives and implications. International Journal of Bank Marketing 16(7): 299-315.

Metwally, M (1996). Attitudes of Muslims towards Islamic banks in a dual-banking system. American Journal of Islamic Finance 6: 11-17.

Metwally, M (2002). The impact of demographic factors on consumers' selection of a particular bank within a dual banking system: a case study. Journal of International Marketing and Marketing Research 27(1): 35-44.

Metwally, M (2003). Attitudes of Consumers in Developing Countries Towards Use of Credit Cards: The Case of the State of Qatar. Journal of International Marketing and Marketing Research 28(2): 83-96.

Naser, K, Jamal A and Al-Khatib K (1999). Islamic banking: a study of customer satisfaction and preference in Jordan. International Journal of Bank Marketing 17(3): 135-150.

Norusis, M (2006). SPSS 15.0 Statistical Procedures Companion. Prentice Hall. Upper Saddle River, N.J.

Obaidullah, M. (2005), Islamic Financial Services, Islamic Economics Research Centre, Jeddah.

Okumus, H (2005). Interest-free banking in Turkey: a study of customer satisfaction and bank selection criteria. Journal of Economic Cooperation 26(4): 51-86.

Omer, H (1992). The Implication of Islamic Beliefs and Practice on Islamic Financial Institutions in the UK. Ph.D. Dissertation, Loughborough University.

Rammal, H and Zurbruegg R (2007). Awareness of Islamic banking products among Muslims: The case of Australia. Journal of Financial Services Marketing. 12(1): 65-74.

Warde, I. (2000), Islamic Finance in the Global Economy, Edinburgh University Press, Edinburgh.

Waters, D (1994). Quantitative Methods for Business. Addison-Wesley Publishing Company. New York.

Zainuddin, Y, Jahyd N and Ramayah T (2004). Perception of Islamic banking: dose it differ among users and non users. Journal of Management \& Business 6(3): 221-232. 
Table 1. Sample characteristics

\begin{tabular}{|c|c|c|c|c|c|c|c|c|c|c|c|}
\hline \multirow[t]{2}{*}{ Variables } & & \multicolumn{2}{|c|}{$\begin{array}{l}\text { All respondents } \\
\quad(n=385)\end{array}$} & \multicolumn{2}{|c|}{$\begin{array}{l}\text { Potential user } \\
\quad(n=331)\end{array}$} & \multicolumn{2}{|c|}{$\begin{array}{c}\text { Not a potential } \\
\text { user }(n=54)\end{array}$} & \multicolumn{2}{|c|}{$\begin{array}{l}\text { Equality of } \\
\text { variances }\end{array}$} & \multicolumn{2}{|c|}{$\begin{array}{l}\text { Equality of } \\
\text { means }\end{array}$} \\
\hline & & Freq. & $\%$ & Freq. & $\%$ & Freq. & $\%$ & F-test & $\mathrm{p}$-value & t-test & p-value \\
\hline Sex & Male & 358 & 92.9 & 306 & 92.4 & 52 & 96.3 & 4.53 & 0.03 & -1.29 & 0.19 \\
\hline \multirow{5}{*}{ Age } & Less than 25 years & 9 & 2.3 & 3 & 0.9 & 6 & 11.1 & 94.11 & $<0.01$ & 2.34 & 0.02 \\
\hline & 26 to 36 years & 79 & 20.5 & 53 & 16.0 & 26 & 48.1 & 45.82 & $<0.01$ & 4.49 & $<\mathbf{0 . 0 1}$ \\
\hline & 36 to 45 years & 123 & 31.9 & 110 & 33.2 & 13 & 24.1 & 9.96 & $<0.01$ & -1.42 & 0.15 \\
\hline & 46 to 55 years & 153 & 39.7 & 148 & 44.7 & 5 & 9.3 & 482.20 & $<0.01$ & -7.33 & $<0.01$ \\
\hline & More than 55 years & 21 & 5.6 & 17 & 5.2 & 4 & 7.4 & 1.79 & 0.18 & 0.68 & 0.49 \\
\hline \multirow{7}{*}{$\begin{array}{l}\text { Highest } \\
\text { level of } \\
\text { education }\end{array}$} & No education & 9 & 2.3 & 9 & 2.7 & 0 & 000 & 11.08 & $<0.01$ & 1.15 & 0.25 \\
\hline & Primary school & 47 & 12.2 & 29 & 8.7 & 18 & 33.4 & 63.54 & $<0.01$ & 3.41 & $<0.01$ \\
\hline & High school & 94 & 24.4 & 87 & 26.2 & 8 & 14.8 & 26.21 & $<0.01$ & -2.55 & 0.01 \\
\hline & Secondary school & 61 & 15.8 & 45 & 13.6 & 16 & 29.6 & 26.22 & $<0.01$ & 2.44 & 0.01 \\
\hline & Diploma & 116 & 30.1 & 107 & 32.3 & 8 & 14.8 & 51.27 & $<0.01$ & -3.22 & $<0.01$ \\
\hline & University & 54 & 14.0 & 51 & 15.3 & 4 & 7.4 & 18.84 & $<0.01$ & -2.64 & $<0.01$ \\
\hline & Postgraduate & 4 & 1.2 & 4 & 1.2 & 0 & 0.0 & 2.69 & 0.10 & -0.81 & 0.41 \\
\hline \multirow{4}{*}{$\begin{array}{l}\text { Employment } \\
\text { status }\end{array}$} & Public sector & 292 & 75.8 & 285 & 86.1 & 7 & 12.9 & 0.24 & 0.62 & -14.25 & $<0.01$ \\
\hline & Private sector & 46 & 11.9 & 39 & 11.8 & 7 & 12.9 & 0.23 & 0.62 & 0.24 & 0.80 \\
\hline & Self-employed & 41 & 10.6 & 4 & 1.2 & 37 & 68.5 & 550.88 & $<0.01$ & 10.50 & $<0.01$ \\
\hline & Retired & 6 & 1.7 & 3 & 0.9 & 3 & 5.6 & 26.35 & $<0.01$ & 1.45 & 0.15 \\
\hline \multirow{4}{*}{$\begin{array}{l}\text { Monthly } \\
\text { income }\end{array}$} & Less than LYD200 & 17 & 4.4 & 17 & 5.1 & 0 & 0.0 & 13.00 & $<0.01$ & -4.22 & $<0.01$ \\
\hline & LYD201 to 300 & 211 & 54.8 & 201 & 60.8 & 10 & 18.5 & 79.54 & $<0.01$ & -7.06 & $<0.01$ \\
\hline & LYD301 to 400 & 138 & 35.8 & 109 & 32.9 & 29 & 53.7 & 6.38 & $<0.01$ & 2.83 & $<0.01$ \\
\hline & More than LYD400 & 19 & 5.0 & 4 & 1.2 & 15 & 27.8 & 428.96 & $<0.01$ & 4.29 & $<0.01$ \\
\hline Nationality & Libyan & 376 & 84.9 & 327 & 98.8 & 49 & 90.7 & 54.54 & $<0.01$ & 1.99 & 0.05 \\
\hline
\end{tabular}

Notes: Tests of equality of variances and means are for the proportion of potential users and non-users of Islamic finance by variable. Levene's test of equality of variances determines whether the test for equality of means assumes equal or unequal variances. Significant test statistics and their p-values in bold. 
Table 2. Awareness and practice of Islamic methods of finance

\begin{tabular}{|c|c|c|c|c|c|c|c|}
\hline \multirow{2}{*}{ Variable } & \multirow[b]{2}{*}{$\begin{array}{l}\text { Knowledge } \\
\text { and practice }\end{array}$} & \multicolumn{2}{|c|}{$\begin{array}{c}\text { All } \\
\text { respondents }\end{array}$} & \multicolumn{2}{|c|}{$\begin{array}{c}\text { Potential } \\
\text { user }\end{array}$} & \multicolumn{2}{|c|}{$\begin{array}{c}\text { Not a potential } \\
\text { user }\end{array}$} \\
\hline & & Freq. & $\%$ & Freq. & $\%$ & Freq. & $\%$ \\
\hline \multirow{2}{*}{$\begin{array}{l}\text { Knowledge of Islamic } \\
\text { banking }\end{array}$} & Yes & 347 & 90.1 & 322 & 92.8 & 25 & 7.2 \\
\hline & No & 38 & 9.9 & 9 & 23.7 & 29 & 76.3 \\
\hline \multirow{3}{*}{$\begin{array}{l}\text { Knowledge of Musharakah } \\
\text { and Quard Hassan }\end{array}$} & Yes & 261 & 67.8 & 245 & 93.8 & 16 & 6.2 \\
\hline & No & 34 & 8.8 & 4 & 11.8 & 30 & 88.2 \\
\hline & Yes & 82 & 21.3 & 77 & 93.9 & 5 & 6.1 \\
\hline \multirow{2}{*}{$\begin{array}{l}\text { Past practice of Quard } \\
\text { Hassan }\end{array}$} & No & 297 & 77.0 & 250 & 84.2 & 47 & 15.2 \\
\hline & Not applicable & 31 & 8.1 & 3 & 9.7 & 28 & 90.3 \\
\hline
\end{tabular}

Table 3. Perceptions of Islamic methods of finance and rotated component matrix

\begin{tabular}{|c|c|c|c|c|c|c|}
\hline \multirow{2}{*}{ Variables } & \multirow[b]{2}{*}{ Mean } & \multirow[b]{2}{*}{ Std. dev. } & \multicolumn{4}{|c|}{ Components } \\
\hline & & & 1 & 2 & 3 & 4 \\
\hline Islamic bank methods of finance are interest-free. & 5.1039 & 1.5594 & 0.287 & 0.306 & 0.816 & 0.065 \\
\hline Islamic bank provides Islamic methods of finance in accordance with Sharia. & 4.6234 & 1.8059 & 0.355 & -0.089 & 0.811 & 0.298 \\
\hline Deposits with Islamic banks would realise a higher variable rate of return. & 3.8078 & 1.4449 & -0.042 & 0.946 & 0.040 & 0.226 \\
\hline Religious motivation for depositing with Islamic bank. & 4.1792 & 1.5483 & 0.271 & 0.044 & 0.919 & 0.063 \\
\hline Islamic bank's cost of borrowing depends on the outcome of the business. & 4.1610 & 1.3010 & 0.153 & 0.592 & 0.084 & -0.016 \\
\hline Religious motivation for borrowing from Islamic bank. & 4.4286 & 1.5396 & 0.227 & 0.012 & 0.911 & 0.091 \\
\hline Islamic bank may invest according to profit sharing method only (Mudarabah). & 3.9117 & 1.4710 & -0.051 & 0.943 & 0.031 & 0.213 \\
\hline Islamic bank lends money according to profit/loss sharing method (Musharakah). & 3.9455 & 1.4876 & -0.047 & 0.940 & 0.040 & 0.213 \\
\hline Profit/loss sharing method allows you to invest or borrow on a fair basis. & 4.1714 & 1.6713 & 0.690 & 0.240 & 0.250 & 0.258 \\
\hline Islamic bank may help in the collection and distribution of Zakah. & 3.9948 & 1.7882 & 0.836 & -0.006 & 0.226 & 0.147 \\
\hline Islamic bank aims to serve Muslim communities. & 3.9325 & 1.4561 & 0.882 & -0.100 & 0.237 & 0.127 \\
\hline Islamic bank may contribute to society’s development. & 4.1922 & 1.6502 & 0.943 & -0.136 & 0.212 & 0.034 \\
\hline Islamic bank provides lease financing (Ijarah). & 3.8935 & 1.5500 & 0.144 & 0.281 & 0.084 & 0.897 \\
\hline Islamic bank provides trade financing methods such as Morabahah. & 3.9143 & 1.3827 & 0.218 & 0.053 & 0.265 & 0.850 \\
\hline Islamic bank provides industrial financing (Istisna). & 3.8000 & 1.4046 & 0.067 & 0.553 & 0.026 & 0.739 \\
\hline Islamic bank may help poor people with benevolent loans (Quard Hassan) & 4.8312 & 1.6724 & 0.725 & 0.329 & 0.397 & 0.013 \\
\hline
\end{tabular}


Table 4. Classification results

\begin{tabular}{llrrr}
\hline \multirow{2}{*}{ Classification } & Predicted group membership & Total \\
\hline & \multicolumn{1}{c}{ Groups } & Potential users & $\begin{array}{c}\text { Not potential } \\
\text { users }\end{array}$ & $\begin{array}{c}\text { Potential } \\
\text { users }\end{array}$ \\
\hline Number & Potential users & 330 & 1 & 331 \\
& Not potential users & 2 & 52 & 54 \\
Percentage of group & Potential users & 99.7 & 0.3 & 100.0 \\
& Not potential users & 3.7 & 96.3 & 100.0 \\
\hline
\end{tabular}

